\title{
PENENTUAN PENGADUKAN OPTIMUM BERDASARAN PENGOMPOSAN DAN PRODUKSI LISTRIK DALAM CSMFCS (COMPOST SOLID PHASE MICROBIAL FUEL CELLS)
}

\author{
Cagayana; Ganjar Samudro; Mochtar Hadiwidodo \\ Departemen Teknik Lingkungan Fakultas Teknik Universitas Diponegoro \\ Jl. Prof. H. Sudarto, SH Tembalang, Semarang, Indonesia 50275 \\ Email: cagayanalp@gmail.com
}

\begin{abstract}
Abstrak
Compost Solid Phase Microbial Fuel Cells adalah salah satu alternatif teknologi pemrosesan sampah organik yang mampu menghasilkan energi yang bersih sebagai hasil dari pengolahan material padat. Masalah dalam CSMFCs adalah masih rendahnya daya listrik yang dihasilkan selama proses berlangsung, sehingga belum dapat diaplikasikan dengan kondisi yang diharapkan. Penelitian ini mengembangkan sebuah sistem CSMFCs menggunakan pengadukan sebagai variabel bebas yang mempengaruhi kinerja CSMFCs, baik dalam menghasilkan kompos matang maupun listrik. Elektroda yang digunakan adalah elektroda graphene yang dirangkai dalam reaktor menggunakan konfigurasi single chamber - air cathode. Volume sampah yang digunakan adalah 2/3 dari volume reaktor dan sumber sampah berasal dari sampah sisa makanan, sampah sisa sayuran, ampas kedelai, dan sampah daun berasal dari pekarangan sekitar Undip yang dioperasikan dalam kondisi batch. Hasil penelitian CSMFCs menunjukkan bahwa kinerja paling optimum terdapat pada frekuensi pengadukan 4 hari sekali. Kompos yang dihasilkan memenuhi ketentuan SNI 19-7030-2004 dan menghasilkan produksi listrik dengan Power Density, Coulombic Efficiency (CE), dan Energy Efficiency (EE) berturutturut sebesar 17,744 mW/m2, 0,6477\%, dan 0,0000733\% pada hari ke 20.
\end{abstract}

Kata Kunci: CSMFC, kinerja, pengadukan

\begin{abstract}
Compost Solid Phase Microbial Fuel Cells are an alternative technology for processing organic waste that can produce clean energy as a result of processing solid materials. The problem with CSMFCs is the low power produced during the process, that it cannot be applied with the expected conditions. This study developed a CSMFCs system using turning frequency as an independent variable in influencing the performance of CSMFCs, both in producing mature compost and electricity. The electrode used was a graphene electrode strung in a reactor using a single chamber - air cathode configuration. The volume of the waste is 2/3 of the reactor volume and the source of waste comes from food waste, vegetable waste, soybean dregs, and leaf waste from the yard around Undip which is operated in batch conditions. The results showed that the most optimum performance was found at a turning frequency every 4 days. The compost result is compatible with SNI 19-7030-2004 and produces electricity with Power Density, Coulombic Efficiency (CE), and Energy Efficiency (EE) respectively $17.744 \mathrm{~mW} / \mathrm{m} 2,0.6477 \%$, and $0.0000733 \%$ on day 20.
\end{abstract}

Keywords: CSMFC, turning frequency, performance

\section{PENDAHULUAN}

Sampah merupakan salah satu hasil samping dari aktivitas manusia yang dipengaruhi oleh pertumbuhan penduduk. Semakin meningkat pertumbuhan penduduk, jumlah timbulan sampah semakin meningkat. Untuk mengurangi jumlah timbulan sampah, dibutuhkan pengolahan sampah. Pengolahan sampah di Indonesia salah satunya dapat dilakukan dilakukan dengan pengurugan, open burning, insinerator skala kecil, dan non pengurugan (Damanhuri dan Padmi, 2010). Terdapat pula 
teknologi lain seperti pengomposan yang umum digunakan untuk mengolah sampah organik. Metode ini menggunakan mikroorganisme alami untuk dekomposisi dan mengubah sampah organik menjadi sampah matang. (Wang et al., 2015). Namun, penanganan sampah organik tersebut tidak memanfaatkan nilai guna sampah di bidang energi baru-terbarukan. Oleh karena itu, dibutuhkan teknologi penanganan sampah yang berfungsi sebagai pereduksi jumlah sampah organik dan dapat memberikan nilai guna terhadap sampah di bidang energi baru-terbarukan.

Sampah organik, salah satunya sampah campuran antara sampah makanan, sampah pasar dan sampah daun, dapat dimanfaatkan sebagai penghasil listrik melalui proses kimiawi dan biologi yang melibatkan mikroorganisme sebagai dekomposisi dan pengubah sampah organik menjadi energi listrik. Penelitian sebelumnya telah dilakukan oleh Muthi'ah (2017) bahwa sampah makanan dan sampah daun dengan variasi jumlah volume sampah yang berbeda dapat menghasilkan listrik dengan daya sebesar 43,8 mW/m². Penelitian lain yang berhubungan dengan sampah makanan, sampah pasar dan dedaunan dilakukan oleh Wang et al. (2013) menggunakan sekam padi, residu kopi, dan kacang yang merupakan sumber sampah dari hasil pertanian dan sampah dapur rumah tangga menghasilkan power density sebesar $264 \mathrm{~mW} / \mathrm{m}^{2}$ dengan menggunakan bioenzim sebagai katalisator. Enzim bekerja untuk memutus rantai panjang selulosa, menghasilkan glukosa dari proses hidrolisis, dan mempercepat perkembangbiakan bakteri sehingga mempercepat dekomposisi.

Dalam pengomposan, faktor pengadukan mempengaruhi proses pengomposan. Menurut Tchobanoglous (1993) dalam Amanah (2012), pengadukan merupakan faktor yang penting dalam mengontrol kelembaban udara agar pengomposan tetap dalam proses aerob. Namun, pengadukan sampah dalam CSMFCs belum pernah diteliti sebelumnya sehingga variabel ini dipilih untuk mengetahui dan menganalisis pengaruh pengadukan terhadap kematangan kompos dan produksi listrik yang dihasilkan dalam CSMFCs. Oleh karena itu, tujuan dari penelitian ini adalah mengetahui frekuensi pengadukan yang optimum dari variasi pengadukan yang ditetapkan sehingga didapatkan pemrosesan CSMFCs yang optimum baik dari segi kualitas kompos maupun listrik. Dalam penelitian ini graphene digunakan sebagai elektroda karena konduktivitas listrik yang tinggi, area permukaan besar, aktivitas elektrokatalitik berlaku, dan biaya produksi yang rendah, (Brownson et al., 2011). Selain itu, penggunaan graphene dalam CSMFC dapat mempertahankan kepadatan arus enam kali lebih tinggi dari tembaga, (Geim 2009) sehingga berpotensi besar untuk dijadikan elektroda pada komponen CSMFCs. 


\section{METODOLOGI PENELITIAN}

Penelitian dilaksanakan di Laboratorium Teknik Lingkungan Universitas Diponegoro Semarang untuk analisis parameter $\mathrm{pH}$, temperatur, rasio $\mathrm{C} / \mathrm{N}$, kadar air, voltase, ampere, dan hambatan, kecuali analisis parameter. Waktu pelaksanaan penelitian di Laboratorium Teknik Lingkungan adalah selama 30 (tiga puluh) hari dimulai dari Mei 2018 hingga Juni 2018.

Dalam penelitian ini dilakukan dengan metode penelitian eksperimental, penelitian yang dilakukan dengan observasi. Penelitian ini dilakukan dengan menggunakan reaktor lab-scale berjumlah 24 reaktor single chamber yang terdiri dari anoda dan katoda, penelitian dilakukan secara destruktif dengan variabel yang telah ditentukan, sehingga total reaktor yang dibutuhkan adalah 24 reaktor. Di dalam reaktor tersebut terdapat dua proses yang terjadi yakni proses aerob di dalam reaktor katoda, dan proses anaerob di dalam reaktor anoda. Penelitian dilakukan dengan variabel yang telah ditentukan. Variabel bebas pada penelitian ini adalah kadar air, volume sampah, dan frekuensi pengadukan. Sedangkan variabel terikat adalah tegangan, kuat arus, power density, coulombic efficiency, dan energy efficiency.

Pengolahan dan analisis data meliputi perhitungan daya/power density, Coulombic Efficiency (CE), Energy Efficiency (EE), C-Organik, N Total, Rasio C/N, P total, K total, dan kadar air. Untuk mendapatkan nilai daya/power density dibutuhkan data tegangan $(\mathrm{V})$, hambatan $(\mathrm{R})$, dan arus listrik (I). Tahapan terakhir dalam penelitian ini yaitu tahap analisis data dimana dilakukan pengambilan data hasil penelitian meliputi parameter pengomposan, produksi listrik, $\mathrm{pH}$ dan temperatur. Pengujian parameter pengomposan dan produksi listrik dilakukan selama 8 hari yakni pada hari ke 0,1,3,5,10,15,20 dan 23. Interval pengambilan data ditentukan berdasarkan fase hidup bakteri pada proses pengomposan. Untuk pengujian temperatur dan $\mathrm{pH}$ dilakukan setiap hari. Pengujian parameter pengomposan dan $\mathrm{pH}$ dilakukan di Laboratorium Undip, sedangkan untuk parameter produksi listrik, dan temperatur dilakukan di TPST Undip. Untuk mengukur produksi listrik di TPST Undip, digunakan multimeter untuk mengdapatkan data tegangan dan hambatan sehingga berdasarkan data tersebut didapatkan data arus, power density, coulombic efficiency, dan energy efficiency berdasarkan hasil perhitungan. Pengambilan data temperatur meggunakan alat berupa termometer ruang. 


\section{HASIL DAN PEMBAHASAN}

\subsection{Temperatur}

Salah satu parameter yang mempengaruhi pengomposan adalah temperatur. Diketahui bahwa variasi temperatur langsung mempengaruhi aktivitas mikroorganisme (Ermolaev et al. 2015).

Gambar 1 menunjukkan fase termofilik pada semua reaktor terjadi pada hari ke 3 dengan temperatur tertinggi pada kadar air 60\% dengan pengadukan 4 hari sekali. Hal ini sesuai dengan penelitian yang dilakukan oleh Kusuma (2012) bahwa temperatur tertinggi terdapat pada kadar air 40\% dan jika dilihat dari data diatas dapat dilihat bahwa kadar air dengan pengadukan 4 hari sekali memiliki temperatur yang lebih tinggi dibandingkan reaktor lainnya. Hal itu disebabkan karena oksigen yang masuk didalam kompos lebih besar dibandingkan dengan kompos yang diaduk selama 7 hari sekali. Aktivitas mikroba pada temperatur tinggi menghasilkan degradasi senyawa organik yang tinggi. Respirasi secara aerob dapat menghasilkan air. Namun, aerasi dan temperatur yang tinggi saat termofilik dapat membuat sumber sampah menjadi kering (Makan \& Mountadar, 2012).

\section{$3.2 \mathrm{pH}$}

$\mathrm{pH}$ dipantau terus menerus setiap harinya karena fluktuasi $\mathrm{pH}$ menunjukkan adanya proses degradasi senyawa organik oleh mikroorganisme. Hasil uji pengukuran pH kompos mengalami fluktuasi. Hasil uji pengukuran $\mathrm{pH}$ dapat dilihat pada gambar 2.

Pada hari ke-0 pengomposan, $\mathrm{pH}$ berada pada nilai netral. Hal ini dikarenakan proses pengomposan baru dilakukan dan proses amonifikasi belum terjdi yang dimana proses amonifikasi adalah fase awal degradasi N-organik. Pada awal pengomposan $\mathrm{pH}$ cenderung naik karena adanya pembentukan ammonia sebagai hasil dari dekomposisi nitrogen yang dipengaruhi pula oleh temperatur (Kim et al., 2007 dalam Cáceres et al., 2018). Peningkatan pH terjadi lebih dulu pada pengadukan yang lebih sering (pengadukan 4 hari sekali). Hal ini sesuai dengan penelitian yang dilakukan oleh Kalamdhad \& Kazmi (2009) bahwa pH lebih tinggi pada reaktor yang diaduk lebih

sering.Saat kompos berada dalam fase bio-oksidatif, $\mathrm{pH}$ dapat naik sampai 8.0-9.0 karena adalanya proses amonifikasi. Pada waktu yang bersamaan, $\mathrm{pH}$ yang tinggi dapat terjadi penguapan $\mathrm{NH}_{3}$ yang melepaskan $\mathrm{NH}_{4}{ }^{+}-\mathrm{N}$ berlebih pada kompos yang dapat menghambat nitrifikasi. Amonifikasi timbul saat fase termofilik dimana nitrifikasi belum terjadi (Cáceres, et al., 2018). Perubahan pH pengomposan berhubungan pula dengan proses nitrifikasi. $\mathrm{pH}$ yang turun dapat dikarenakan adanya permbentukan nitrat yang menyebabkan adalanya $\mathrm{H}+$ yang dilepaskan saat nitrifikasi (Eklind dan 
Kirchmann, 2000 dalam Cáceres et al., 2018). Penurunan pH juga disebabkan karena adanya produksi asam organik saat proses dekomposisi (Getahun et al. 2012) yang menghasilkan pH rendah pada akhir pengomposan.

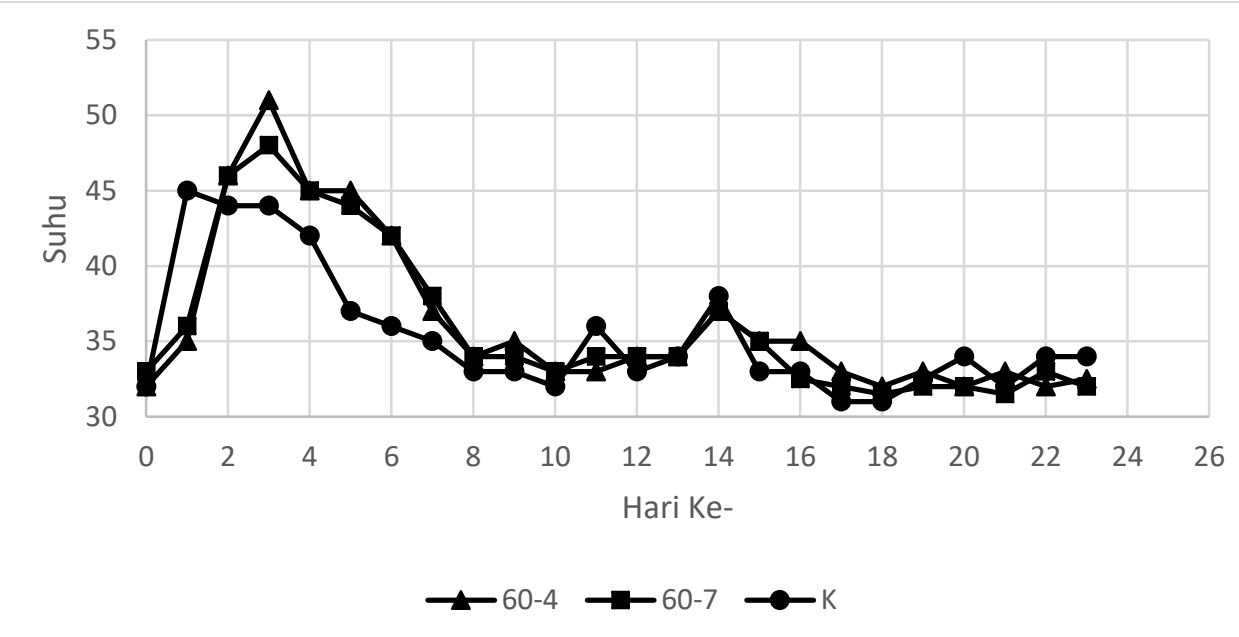

Gambar 1. Hasil Pengukuran Temperatur Kompos

Keterangan: 60-4 = kadar air 60\% dengan pengadukan 4 hari sekali

60-7 = kadar air $60 \%$ dengan pengadukan 7 hari sekali

$\mathrm{K}=$ reaktor kontrol

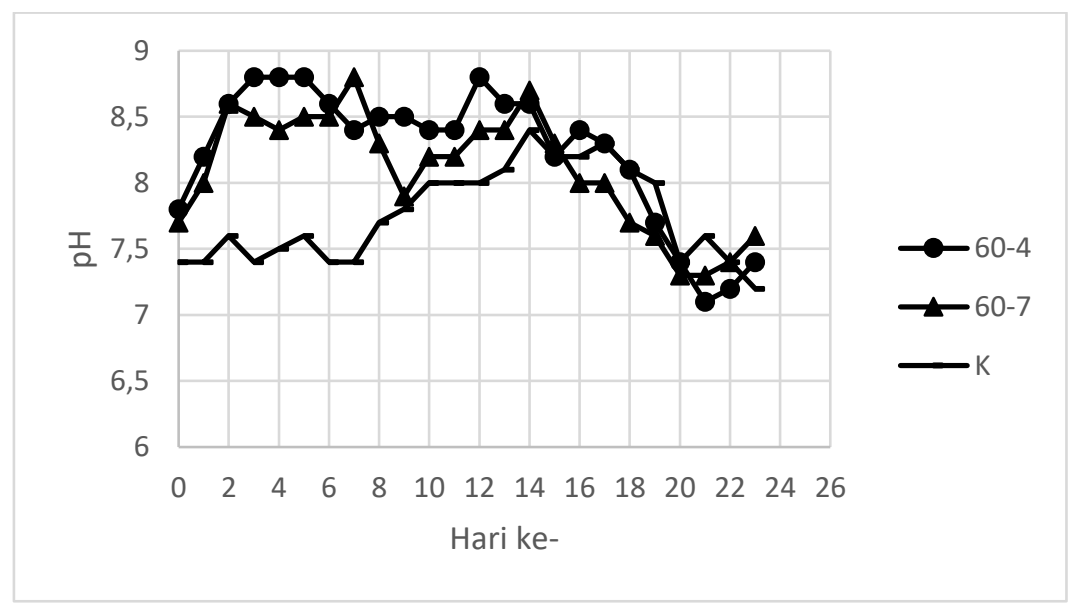

Gambar 2. Pengukuran pH Kompos

Keterangan: 60-4 = kadar air 60\% dengan pengadukan 4 hari sekali

60-7 = kadar air $60 \%$ dengan pengadukan 7 hari sekali

$K=$ reaktor kontrol 


\subsection{Kadar C-Organik dan N-Total}

Senyawa organik termineralisasi setelah pengomposan, sebagian besar karena degradasi senyawa yang mudah terdegradasi seperti protein, selulosa, dan hemi-selulosa yang digunakan mikroorganisme sebagai sumber $\mathrm{C}$ dan N. Total Karbon berguna untuk menentukan umur dan ciriciri fisik dari kompos. Saat proses pengomposan, $\mathrm{CO}_{2}$ dilepaskan melalui pengomposan sebagai produk akhir metabolisme (Kalamdhad et al., 2009)

Dari segi pengadukan, reaktor dengan pengadukan 4 hari sekali memiliki kadar C-Organik yang lebih rendah dibandingkan dengan reaktor pengadukan 7 hari sekali. Hal ini dikarenakan oleh frekuensi pengadukan yang lebih sering sehingga adanya peningkatan oksigen di dalam kompos yang menyebabkan aktivitas mikroorganisme meningkat (Jiang-ming 2017). Untuk kadar N-Total, penurunan terjadi pada hari ke 10 sampai dengan hari ke 15. Hal ini sesuai dengan pernyataan Huang et al. (2004) dalam Kalamdhad et al. (2009) bahwa total nitrogen naik setelah hari ke 15 pengomposan karena hilangnya massa kering karena terbentuknya $\mathrm{CO}_{2}$ dan hilangnya air melalui penguapan yang disebabkan oleh terbentuknya panas saat oksidasi senyawa organik.

Dari gambar 3 dapat diketahui bahwa kadar C-Organik dan N-Total pada seluruh reaktor di akhir pengomposan memenuhi ketentuan dari SNI 19-7030-2004. C-Organik dengan pengadukan 4 hari sekali pada akhir pengomposan sebesar $21,15 \%$ sedangkan untuk pengadukan 7 hari sekali sebesar $23,17 \%$. N-Total pada akhir pengomposan untuk pengadukan 4 hari sekali sebesar $1,30 \%$ sedangkan untuk 7 hari sekali sebesar $1,35 \%$.

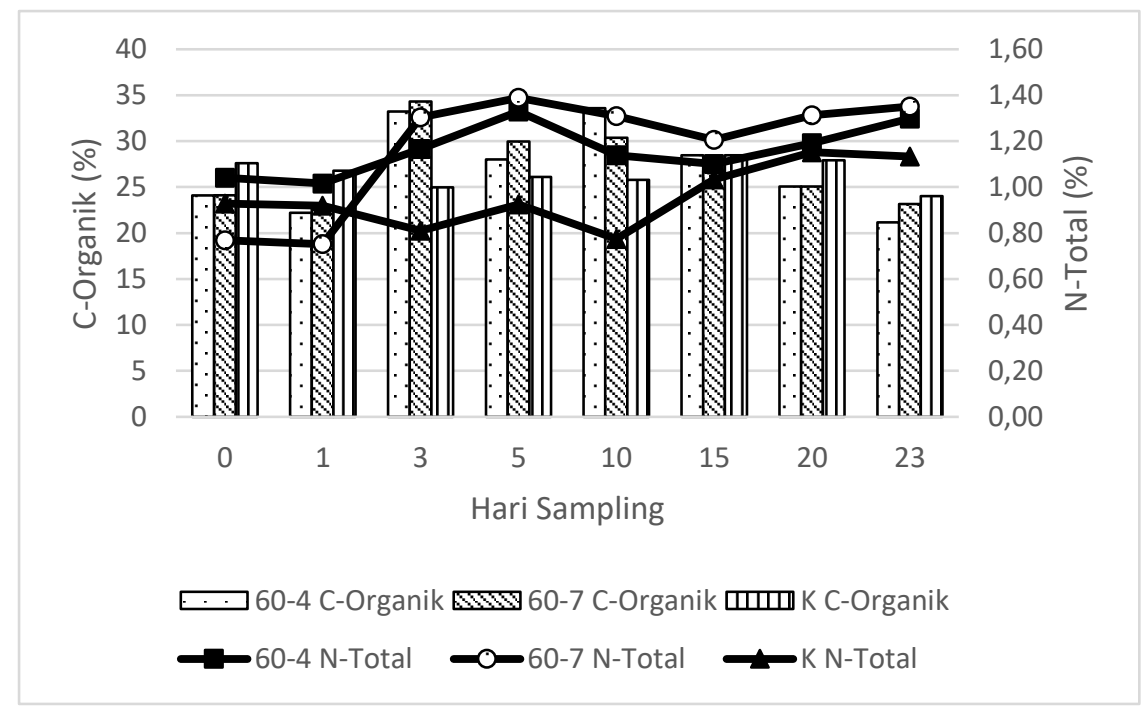

Gambar 3. Pengukuran C-Total dan N-Total Kompos 


\subsection{Rasio C/N}

Parameter yang paling sering digunakan dalam pengomposan adalah rasio $\mathrm{C} / \mathrm{N}$ awal pengomposan. Umumnya, rasio C/N sebesar 25 sampai 38 menghasilkan pengomposan yang baik (Jindo et al., 2016 dalam Waqas et al., 2018). C/N adalah elemen kritis yang dibutuhkan untuk dekomposisi mikroorganisme.

Jika dilihat dari gambar 4, rasio C/N mengalami fluktuasi pada setiap reaktor. Rasio C/N pada kompos mengalami kenaikan dari hari ke 0 sampai dengan hari ke 3 untuk reaktor 60-4 kemudian kenaikan kembali terjadi pada hari ke 10, kemudian turun dari hari ke 15 sampai dengan hari 23 . Untuk reaktor 60-7, rasio C/N menglami penurunan sampai hari ke 5, kemudian ada kenaikan sampai hari ke 10 kemudian turun kembali sampai hari ke 23. Kenaikan rasio $\mathrm{C} / \mathrm{N}$ dapat disebabkan oleh kuatnya volatilisasi $\mathrm{NH}_{3}$ saat pengomposan. Kenaikan rasio $\mathrm{C} / \mathrm{N}$ juga dilaporkan pada pengomposan terdahulu (Eghball et al., 1997; Tiquia dan Tam, 2000 dalam Ogunwande et al., 2008).

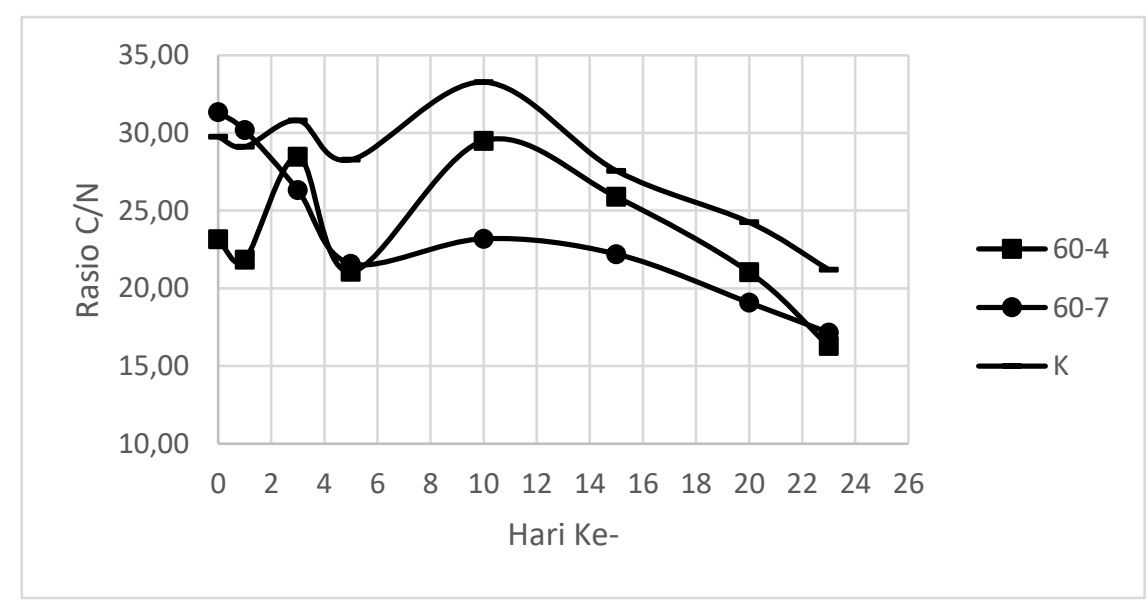

Gambar 4. Pengukuran Rasio C/N Kompos

Dari segi pengadukan, reaktor dengan pengadukan 7 hari sekali memiliki rasio $\mathrm{C} / \mathrm{N}$ yang lebih tinggi dibandingkan pengadukan 4 hari sekali. Rasio tertinggi dicapai oleh reaktor K sebesar 21,2\%. Dari Gambar 4 dapat diketahui bahwa kadar Rasio C/N pada reaktor 60-4 dan reaktor 60-7 di hari akhir pengomposan memenuhi ketentuan dari SNI 19-7030-2004 yakni rasio sekitar 10-20\%. Reaktor K belum memenuhi ketentuan dikarenakan laju degradasi senyawa organik yang lambat. Kadar air dan pengadukan tidak diatur dalam reaktor $\mathrm{K}$ sehingga mempengaruhi hasil dari Rasio $\mathrm{C} / \mathrm{N}$ pada reaktor K. 


\subsection{Kadar P-Total}

Jika dilihat dari Gambar 5, pada reaktor 60-4, kadar fosfor mengalami kenaikan sampai hari ke 5 kemudian mengalami penurunan sampai hari ke 10 dan naik kembali sampai hari ke 23. Untuk reaktor 60-7, kadar fosfor mengalami kenaikan sampai hari ke 10 kemudian terjadi penurunan di hari ke 15 dan naik kembali sampai hari ke 23. Penurunan kadar fosfor dapat disebabkan oleh mineralisasi dari fosfor organik dan pemakaian fosfor oleh mikroba (Kalamdhad et al., 2009). Sedangkan konsentrasi $\mathrm{P}$ yang naik dikarenakan besarnya massa dry matter yang hilang yang pada dasarnya massa yang sama pada Fosfor berada pada massa dry matter yang lebih rendah (Larney et al. 2006).

Dari Gambar 5 dapat diketahui bahwa kadar kadar Fosfor pada reaktor kontrol di hari akhir pengomposan tidak memenuhi ketentuan dari SNI 19-7030-2004 yakni kadar fosfor $>0.1 \%$. hal ini dapat terjadi karena jadwal pengadukan dan kadar air tidak diatur sehingga degradasi P-Total tidak memenuhi kriteria dari SNI. Untuk reaktor dengna pengadukan 4 hari sekali memenuhi ketentuan dari SNI yaitu sebesar 0,129\%, sedangkan untuk reaktor 7 hari sekali P-Total yang dihasilkan pada akhir pengomposan sebesar $0,111 \%$.

\subsection{Kadar K-Total}

Pengikat unsur kalium berasal dari hasil dekomposisi bahan organik oleh mikroorganisme. Adanya dekomposisi memecah senyawa organik kompleks menjadi sederhana sehingga dapat diserap oleh tanaman. Kalium berperan dalam fotosintesis pembentukan protein dan selulosa. (Winarso, 2005 dalam Widarti et al., 2015).

Kompos dengan frekuensi pengadukan yang lebih tinggi menghasilkan kadar kalium yang tinggi pula. Ini mengindikasikan bahwa aktivitas mikroba lebih tinggi saat pengadukan, menghasilkan mineralisasi yang tinggi juga (Jiang-min, 2017).

Dari Gambar 5 dapat diketahui bahwa kadar kadar kalium pada seluruh reaktor di hari akhir pengomposan memenuhi ketentuan dari SNI 19-7030-2004 yakni kadar kalium >0.2\%. Untuk reaktor dengan pengadukan 4 hari sekali K-Total yang dihasilkan sebesar 1,95\%. Pada reaktor 7 hari sekali, K-Total yang dihasilkan sebesar $1,764 \%$.

\subsection{Power Density}

Daya sering dinormalisasikan dalam beberapa karakteristik reaktor agar dapat dibandingkan dari sistem yang berbeda. Parameter yang dipilih untuk normalisasi bergantung pada aplikasi, karena banyak sistem yang tidak menghasilkan daya yang optimal. 
Berdasarkan Gambar 6 didapatkan nilai arus setiap hari sampling. Pada reaktor 60-4, PD terbesar dihasilkan pada hari ke 20 yaitu sebesar $17.74 \mathrm{~mW} / \mathrm{m}^{2}$, sedangkan reaktor 60-7 menghasilkan PD terbesar pada hari ke 0 yaitu sebesar $8,41 \mathrm{~mW} / \mathrm{m}^{2}$.

Dalam penelitian yang dilakukan oleh Wang et al. (2013) diketahui bahwa kadar air $60 \%$ yang merata adalah kondisi paling ideal pada Solid Phase Microbial Fuel Cell (SMFC). Selain itu, penelitian yang dilakukan oleh Wang et al. (2015) menunjukkan power density dihasilkan lebih baik pada kadar air $60 \%$ yaitu sebesar $4.6 \mathrm{~mW} / \mathrm{m}^{2}$. Pengadukan dengan frekuensi yang lebih sering menambah sirkulasi oksigen di dalam reaktor sehingga reaktor dengan pengadukan 4 hari sekali menghasilkan daya yang lebih besar dibandingkan reaktor dengan pengadukan 7 hari sekali.

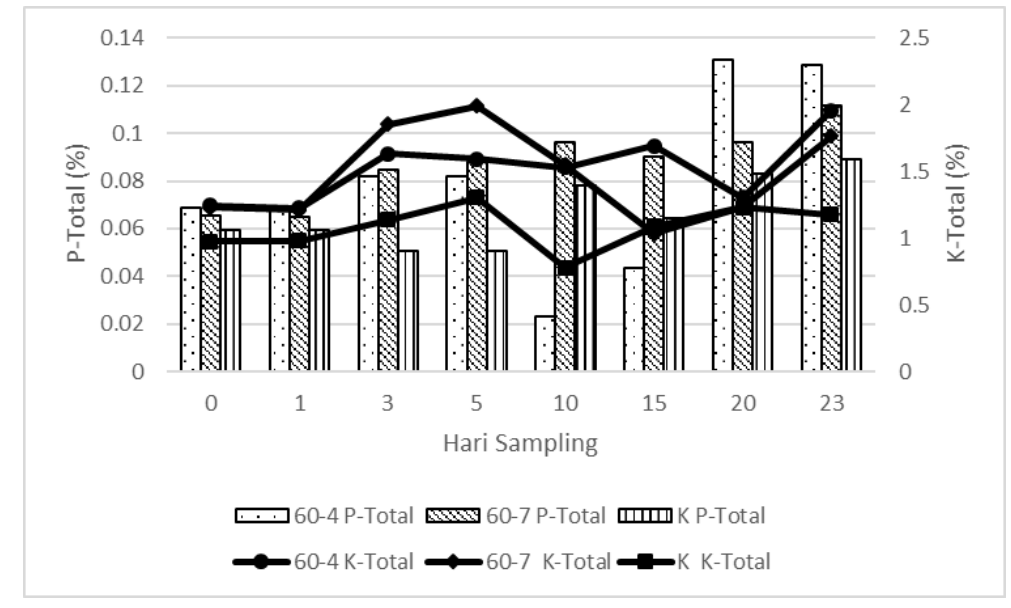

Gambar 5. Pengukuran P-Total dan K-Total Kompos

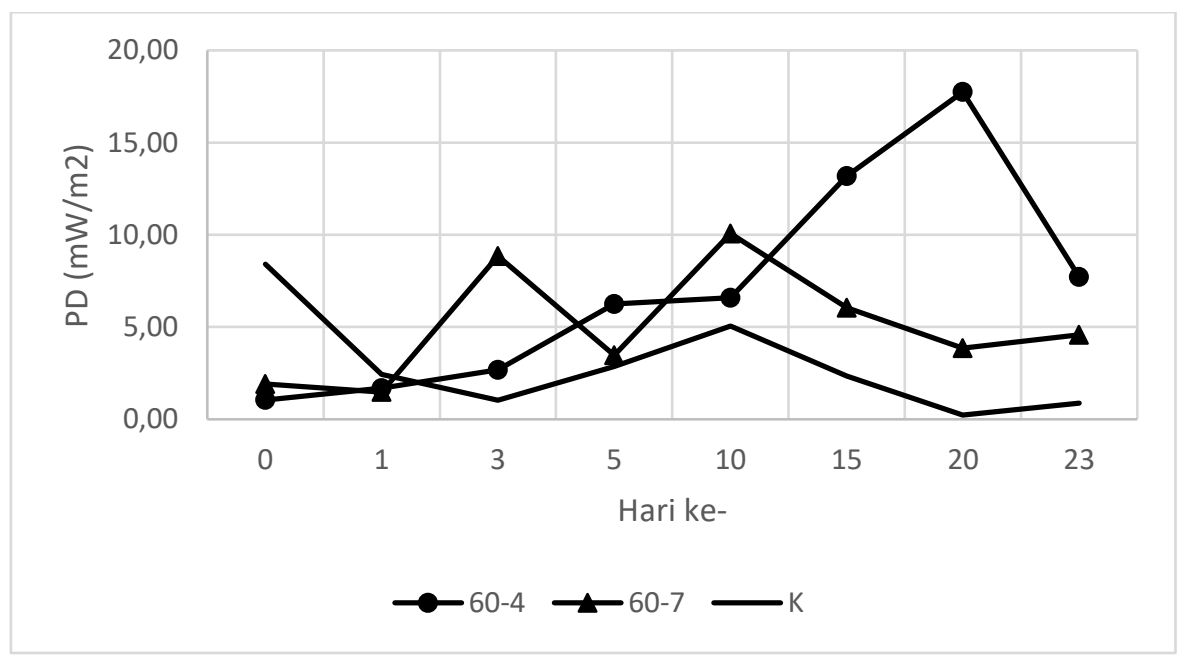

Gambar 6. Power Density pada CSMFC 


\subsection{Coulombic Efficiency (CE)}

Berdasarkan gambar 7 didapatkan nilai CE setiap hari sampling. Reaktor 60-4, CE terus mengalami kenaikan dan CE terbesar dihasilkan pada hari ke 20 yaitu sebesar 0,648\%, sedangkan reaktor 60-7 cenderung mengalami kenaikan dan menghasilkan PD terbesar pada hari ke 15 yaitu sebesar $0.5532 \%$ kemudian mengalami penurunan pada hari ke 20 dan kembali naik pada hari ke 23 dengan CE akhir pada reaktor $60-7$ sebesar $0.493 \%$.

Karena listrik dihasilkan melalui degradasi senyawa organik, merupakan hal yang penting untuk mengetahui CE pada setiap substrat pada setiap variasi konsentrasi. Penelitian yang dilakukan oleh Sharma et al., 2010 meunjukkan bahwa nilai CE berkurang seiring dengan naiknya konsentrasi substrat. Alasan utama CE berbanding terbalik dengan konsentrasi substrat adalah karena konsentrasi substrat yang tinggi menghambat aktivitas bakteri (Shen dan Wang, 1994 dalam Sharma et al., 2010). Sehingga mengurangi nilai CE. Terdapat dua faktor dihasilkan CE yang rendah. Pertama, substrat dikonsumsi oleh bakteri dan tidak digunakan untuk produksi listrik. Kedua, senyawa organik dan elektron dikonsumsi oleh akseptor elektron (seperti oksigen, nitrat, dan sulfat) yang ada di media tersebut (Sharma et al., 2010).

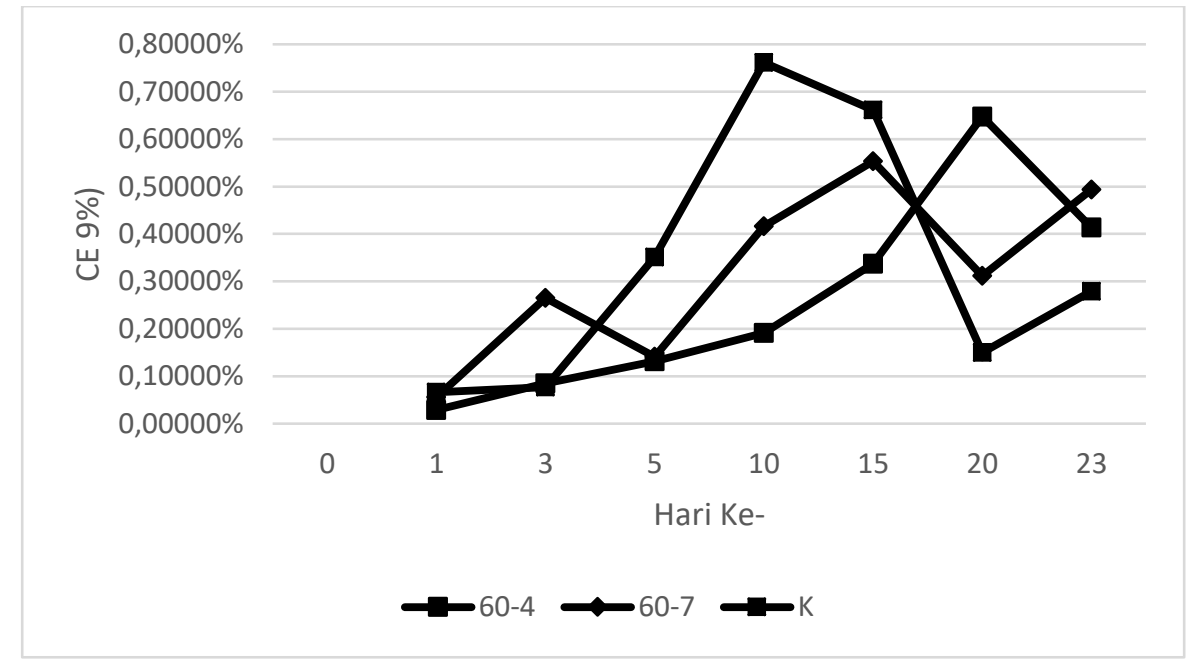

Gambar 7. Coulombic Efficiency pada CSMFC

\subsection{Energy Efficiency (EE)}

Pada sistem MFC, Efisiensi Energi (EE) adalah salah satu hal yang paling umum untuk ditinjau yang menjadi acuan untuk suatu sistem MFC dapat diaplikasikan atau tidak dalam teknologi praktis (Lee et al., 2008).

Berdasarkan Gambar 8 reaktor 60-4, EE mengalami kenaikan sampai pada hari ke 20 dengan EE sebesar $0.0000733 \%$, sedangkan reaktor 60-7 menghasilkanEE terbesar pada hari ke 23 yaitu sebesar 
$0.0000217 \%$. Pada fuel cell konvensional, Efisiensi potensial menurun karena adalanya energi yang hilang melalui ohmic losses, concentration losses, dan activation losses. Ohmic losses dipengaruhi karena adanya resistensi arus pada elektroda dan interkoneksi sirkuit, bersamaan dengan resistansi dalam mengalirkan ion dalam elektrolit dan memalui Cation Exchange Membrane (CEM). Concentration losses terjadi saat oksidasi pada substrat di anoda atau redusi pada katoda lebih cepat dibandingkan kecepatan transfer substrat pada elektrode (Lee et al., 2008). Dalam penelitian yang dilakukan oleh Liu dan Logan (2004), persentase energi efisiensi dalam MFC berkisar antara 2\% $50 \%$ menggunakan substrat yang mudah terdegradasi. Sebagai perbandingan, energi efisiensi listrik untuk konversi termal pada metana $<40 \%$ (Logan 2008).

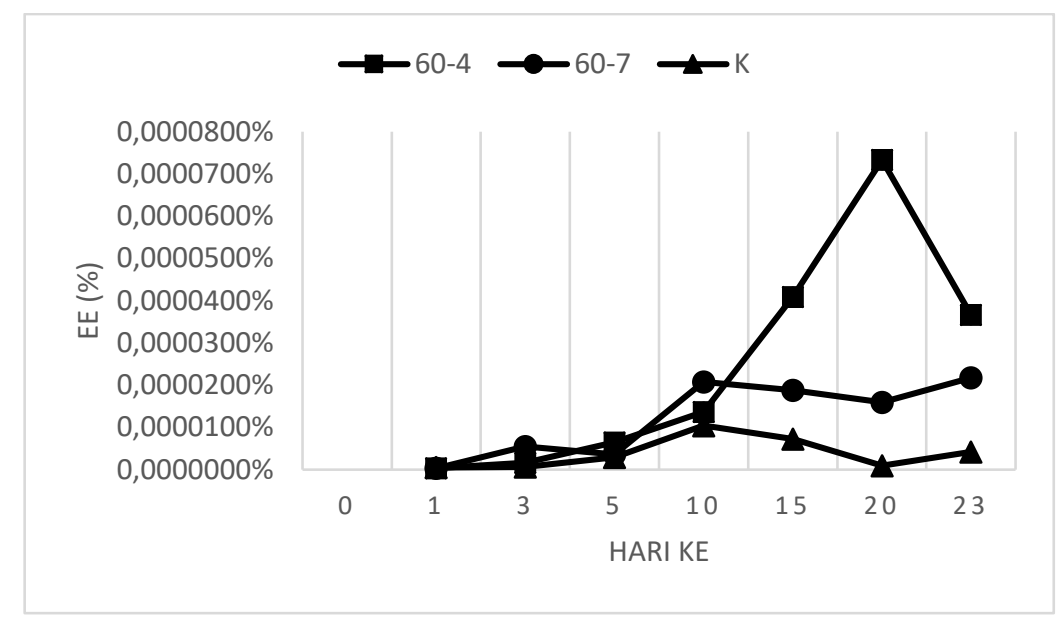

Gambar 8. Energy Efficiency pada CSMFC

\section{KESIMPULAN}

Berdasarkan penelitian yang telah dilakukan berikut kesimpulan yang dapat diperoleh hal, yaitu:

1. Frekuensi pengadukan yang lebih tinggi mempercepat degradasi sampah organik. Selain itu, frekuensi pengadukan yang lebih tinggi memudahkan bakteri dalam mentransfer elektron dari sampah organik sehingga dihasikan listrik. Dalam penelitian ini frekuensi pengadukan tertinggi adalah 4 hari sekali.

2. CSMFC dengan pengadukan 4 hari sekali (60-4) menghasilkan C-Organik, N-Total, Rasio C/N, P-Total, dan K-Total optimum yang berturut-turut sebesar 21,15\%, 13,3\%, 16,29\%, 3,473\%, dan 1,96\%. Sedangkan untuk produksi listrik, PD, CE dan EE optimum yang didapatkan berturut-turut sebesar $17,744 \mathrm{~mW} / \mathrm{m}^{2}, 0,6477 \%$, dan $0,0000733 \%$. 


\section{DAFTAR PUSTAKA}

Amanah, F., (2012), Pengaruh Pengadukan Dan Komposisi Bahan Kompos Terhadap Kualitas Kompos Campuran Lumpur Tinja, Skripsi, Universitas Indonesia, Jakarta, Indonesia.

Brownson, D. A. C., Kampouris, D. K., Banks, C. E., 2011, An Overview of Graphene in Energy Production and Storage Applications, Journal of Power Sources, 196(11), pp. 4873-4885.

Cáceres, R., Malińska, K., Marfà, O., (2018), Nitrification within Composting: A Review, Waste Management, 72, pp. 119-137.

Damanhuri, E., Padmi, T., (2010), Pengelolaan Sampah, Diktat Program Studi Teknik Lingkungan, Institut Teknologi Bandung, Bandung, Indonesia, pp. 30.

Ermolaev, E., Jarvis, A., Sundberg, C., Smars, S., Pell, M., Jönsson, H., (2015), Nitrous Oxide and Methane Emissions from Food Waste Composting at Different Temperatures, Waste Management, 46, pp. 113-119.

Geim, A. K., (2009), Graphene: Status and Prospects, Prospects, 324, pp. 1-8.

Getahun, T., Nigusiea, A., Entelea, T., Gerven, T. V., Van derBruggen, B., (2012). Effect of Turning Frequencies on Composting Biodegradable Municipal Solid Waste Quality, Resources, Conservation and Recycling, 65, pp. 79-84.

Jiang-ming, Z., (2017), Effect of Turning Frequency on Co-Composting Pig Manure and Fungus Residue, Journal of the Air and Waste Management Association, 67(3), pp. 313-321.

Kalamdhad, A., Kazmi, (2009), Effects of Turning Frequency on Compost Stability and Some Chemical Characteristics in a Rotary Drum Composter, Chemosphere, 74(10), pp. 1327-1334. Kusuma, M. A., (2012). Pengaruh Variasi Kadar Air Terhadap Laju Dekomposisi Sampah Organik Di Kota Depok, Tesis, Universitas Indonesia, Depok, Indonesia.

Larney, Francis, J., Katherine, E., Buckley, Hao, X., McCaughey, W. P., (2006). Fresh, Stockpiled, and Composted Beef Cattle Feedlot Manure, Journal of Environment Quality, 35(5), pp. 1844.

Lee, H. S., Parameswaran, P., Kato-Marcus, A., Torres, C. I., Rittmann, B. E., (2008), Evaluation of Energy-Conversion Efficiencies in Microbial Fuel Cells (Mfcs) Utilizing Fermentable and Non-Fermentable Substrates, Water Research, 42(6-7), pp. 1501-1510.

Liu, H., Logan, B. E., (2004), Electricity Generation Using an Air-Cathode Single Chamber Microbial Fuel Cell in the Presence and Absence of a Proton Exchange Membrane, Environmental Science \& Technology, 38(14), pp. 4040-4046.

Logan, B. E., (2008), Microbial Fuel Cells, John Wiley \& Sons, USA, pp. 44-60. 
Muthi'ah, H., (2017), Pengaruh Variasi Volume Sampah Padat Organik Dan Sumber Bakteri Terhadap Kinerja Solid Phase Microbial Fuel Cell (SMFC), Skripsi, Universitas Diponegoro, Semarang, Indonesia.

Makan, A., Mountadar, M., (2012), Effect of C / N Ratio on the in-Vessel Composting under Air Pressure of Organic Fraction of Municipal Solid Waste in Morocco, Journal of Material Cycles and Waste Management, 14(3), pp. 241-249.

Ogunwande, G. A., Osunade, J. A., Adekalu, K. O., Ogunjimi, L. A. O., (2008), Nitrogen Loss in Chicken Litter Compost as Affected by Carbon to Nitrogen Ratio and Turning Frequency, Bioresource Technology, 99(16), pp. 7495-7503.

Sharma, Yogesh, Li, B., (2010), The Variation of Power Generation with Organic Substrates in Single-Chamber Microbial Fuel Cells (SCMFCs), Bioresource Technology, 101(6), pp. 18441850.

Wang, Tsan, C., Liao, F. Y., Liu, K. S., (2013), Electrical Analysis of Compost Solid Phase Microbial Fuel Cell, International Journal of Hydrogen Energy, 38(25), pp. 11124-11130.

Wang, Tsan, C., Lee, Y. C., Liao, F. Y., (2015), Effect of Composting Parameters on the Power Performance of Solid Microbial Fuel Cells, Sustainability (Switzerland), 7(9), pp. 1263412643.

Waqas, M., Nizamib, A. S., Aburiazaizaa, A. S., Barakata, M. A., Rashid, M. I., Ismail, M. I., Optimizing the Process of Food Waste Compost and Valorizing Its Applications: A Case Study of Saudi Arabia, Journal of Cleaner Production, 176, pp. 426-438.

Widarti, Nining, B., Wardhini, W. K., Sarwono, E., (2015), Pengaruh Rasio C/N Bahan Baku Pada Pembuatan Komppos Dari Kubis dan Kulit Pisang, Integrasi Proses, 5(2), pp. 77. 